IDEOLOGY AND CINEMATOGRAPHY IN HOLLYWOOD, 1930-39 
Also by Mike Cormack

IDEOLOGY 


\section{Ideology and Cinematography in Hollywood, 1930-39}

\section{Mike Cormack}

Lecturer in Film and Media Studies

University of Stirling 


\section{(C) Mike Cormack 1994}

Softcover reprint of the hardcover 1st edition 1994 978-0-333-53443-4

All rights reserved. No reproduction, copy or transmission of this publication may be made without written permission.

No paragraph of this publication may be reproduced, copied or transmitted save with written permission or in accordance with the provisions of the Copyright, Designs and Patents Act 1988, or under the terms of any licence permitting limited copying issued by the Copyright Licensing Agency, 90 Tottenham Court Road, London W1P 9HE.

Any person who does any unauthorised act in relation to this publication may be liable to criminal prosecution and civil claims for damages.

First published 1994 by

THE MACMILLAN PRESS LTD

Houndmills, Basingstoke, Hampshire RG21 2XS

and London

Companies and representatives

throughout the world

ISBN 978-1-349-11860-1

ISBN 978-1-349-11858-8 (eBook)

DOI 10.1007/978-1-349-11858-8

A catalogue record for this book is available

from the British Library. 


\section{Contents}

1 Introduction 1

Explaining cinematographic style 1

The studio system $\quad 6$

Defining 'style'

Method 7

2 Ideology and Cinematographic Style 9

$\begin{array}{ll}\text { The articulated definition } & 9\end{array}$

The minimal concept of the dominant ideology 10

$\begin{array}{ll}\text { Hegemony } & 12\end{array}$

Determination 13

Popular film 13

The audience $\quad 14$

From ideology to visual style 15

$\begin{array}{ll}\text { The elements of cinematographic style } & 16\end{array}$

Cinematography as a system of signification 19

Cinematographic structuring 21

Cinematography as a system of subjectivity 23

Conclusion 26

3 From Silent to Sound: All Quiet on the Western Front 27

The making of All Quiet on the Western Front 27

The script $\quad 29$

Camera movement $\quad 30$

Camera distance $\quad 32$

Camera angle $\quad 33$

Lighting $\quad 35$

Signification $\quad 37$

Subjectivity 41

Conclusion $\quad 42$

4 A Crisis of Explanation: The Early Thirties 44

The crisis of the early thirties 44

Hollywood in the Depression 46 
Cinematographic style, 1931-32 47

The Public Enemy 49

Susan Lenox, Her Fall and Rise $\quad 52$

The Most Dangerous Game 55

Ideological contradictions in films of the early thirties 57

Conclusion $\quad 59$

5 Questioning Subjectivity: Dr Jekyll and Mr Hyde 61

The making of Dr Jekyll and Mr Hyde 61

Stevenson's story $\quad 63$

Camera movement 64

Camera distance $\quad 66$

Camera angle $\quad 68$

Lighting $\quad 70$

Signification $\quad 71$

Subjectivity $\quad 74$

$\begin{array}{ll}\text { Conclusion } & 75\end{array}$

6 The New Deal in Hollywood, 1933-35 77

The economy and society in the mid-thirties 77

Hollywood and the Production Code $\quad 80$

Technological developments in the mid-thirties $\quad 82$

42nd Street $\quad 84$

Viva Villa! $\quad 86$

Bride of Frankenstein $\quad 88$

Les Miserables $\quad 90$

Conclusion $\quad 92$

7 Screwball Restraint: The Awful Truth 93

The making of The Awful Truth 93

Screwball comedy $\quad 94$

$\begin{array}{ll}\text { The script } & 97\end{array}$

Camera movement $\quad 98$

Camera distance 100

Camera angle 102

Lighting 102

Signification 104

Subjectivity 105

Conclusion 106

8 The Restrained Style, 1936-38 108

The studios in the mid-thirties 108

The Adventures of Robin Hood 111 
$\begin{array}{ll}\text { Three Comrades } & 114\end{array}$

Ideology in Three Comrades and The Adventures of Robin Hood 119

Conclusion

9 Towards Film Noir: Dead End 123

The making of Dead End 123

$\begin{array}{lr}\text { The script } & 125\end{array}$

$\begin{array}{lr}\text { Camera movement } & 127\end{array}$

$\begin{array}{lr}\text { Camera distance } & 129\end{array}$

$\begin{array}{lr}\text { Camera angle } & 130\end{array}$

$\begin{array}{lr}\text { Lighting } & 131\end{array}$

$\begin{array}{lr}\text { Deep focus } & 133\end{array}$

$\begin{array}{lr}\text { Signification } & 134\end{array}$

$\begin{array}{ll}\text { Subjectivity } & 136\end{array}$

$\begin{array}{lr}\text { Conclusion } & 137\end{array}$

10 The End of the Decade 138

$\begin{array}{ll}\text { The USA at the end of the thirties } & 138\end{array}$

$\begin{array}{ll}\text { Hollywood reacts } & 140\end{array}$

$\begin{array}{ll}\text { Film style at the end of the decade } & 142\end{array}$

The Hound of the Baskervilles 143

Gone With the Wind 146

$\begin{array}{lr}\text { Conclusion } & 151\end{array}$

$\begin{array}{lr}\text { Conclusion } & 152\end{array}$

$\begin{array}{ll}\text { Notes } & 154\end{array}$

$\begin{array}{ll}\text { Select Bibliography } & 161\end{array}$

$\begin{array}{lr}\text { Index } & 163\end{array}$ 


\section{Acknowledgements}

Thanks are due to John Izod who supervised the doctoral thesis on which this book is based, and to John Caughie and Phillip Drummond, the examiners of the thesis, whose suggestions helped its transformation into a book. Particular thanks are due to Chris. Without her encouragement the writing of both thesis and book would have taken much longer and been much more onerous. 